\title{
Characteristics of female victims of assault attending a Scottish accident and emergency department
}

\author{
John Wright, Ash Kariya
}

\begin{abstract}
Objective-To compare the characteristics of female victims of assault with those of male victims and to see if there is a difference between female victims of domestic assault and females assaulted by strangers or acquaintances.

Design-A two month prospective study (June and July 1995) of all assault victims attending a Scottish accident and emergency (A\&E) department

Setting-A large district general A\&E department (the Royal Alexandra Hospital in Paisley) seeing 60000 new patients per year with a catchment population of 200000.

Results-46 female victims of violence attended the A\&E department (20\% of the total of 235). In comparison with men, women were more likely to be assaulted in their homes $(48 \% v 10 \% ; P<0.001)$, but were less likely to be assaulted with sharp weapons $(7 \% v 28 \% ; P=0.003)$ and to require admission to hospital $(P=0.005)$. Nineteen women $(41 \%)$ were victims of domestic assault. The victims of domestic assault were more likely to have been drinking $(11 \% v 31 \% ; P=0.007)$ and to have a history of previous assault (63\% $v$ $22 \% ; P=0.002)$. This group also had a higher mean deprivation score and rate of unemployment, although the differences were not statistically significant.

Conclusions-A\&E staff should be aware of risk factors associated with domestic assault to aid recognition of victims. Using the current British Association for Accident and Emergency Medicine guidelines on domestic violence and closer liaison with police, social services, and general practitioners will help prevent further attacks.

( Accid Emerg Med 1997;14:375-378)
\end{abstract}

Department of

Accident and

Emergency, Royal

Alexandra Hospital,

Paisley, Scotland, UK

J Wright

A Kariya

Correspondence to:

Dr John Wright, Department of Accident and Emergency,

Royal Alexandra Hospital,

Paisley PA2 9PN, UK.

Accepted for publication 12 August 1997
Keywords: alcohol; assault; unemployment; women

Most studies on violence concentrate on males, as they form the majority of victims. However, a significant amount of violence is directed towards women. The evidence suggests that there is a different aetiology of violence in women. Within the female victim group there is a large subgroup-victims of domestic violence. In the 10 years up to 1994 , $70 \%$ of Scottish female homicide cases were victims of domestic assault, while only $20 \%$ of male victims were. ${ }^{1}$

Descriptive studies from United Kingdom accident and emergency (A\&E) departments give a prevalence of home based violence of $13-20 \%$ and a prevalence of domestic assault of $9-16 \%$ of the total number of assaults. ${ }^{2-4}$ However, these figures are probably underestimates, as specific research into domestic assault reveals that patients underreport domestic violence and doctors often fail to recognise vital clues, missing the opportunity to help the victim. In the United States, Hamberger et al carried out an anonymous survey into domestic assault on all women seeking health care in a family practice in Wisconsin. Of those agreeing to participate, the lifetime rate of physical abuse was $39 \%$, but only $2 \%$ of those interviewed had ever been asked about physical abuse by their doctors. ${ }^{5}$ A review in the fournal of the American Medical Association in 1990 indicated that although large numbers of battered women seek medical care, both generally and for acute injuries, only a small percentage were identified by their doctors as battered. ${ }^{6}$ In London, Gayford interviewed 100 battered wives, most of whom were in a woman's aid hostel. He reported that most wives were subject to repeated violence, but they often tried to pass their injuries off as accidents, and the general practitioner was often presented with vague physical or mental symptoms. $^{7}$

This study was part of a larger A\&E department audit of assault. By analysing risk factors in female victims of domestic assault and female victims of assault other than by a relative or partner, it was hoped to identify certain factors associated with domestic assault to aid health workers in recognising victims who would otherwise return to the "cycle of violence."

\section{Methods}

The survey was carried out in the accident and emergency department of the Royal Alexandra Hospital in Paisley. Every assault patient attending the department in the months of June and July 1995 was included. Before beginning data collection, medical receptionists, nurses, and casualty doctors were instructed to be aware of any assault patients attending the department.

Ten casualty doctors were involved in interviewing and examining the victims and each one incorporated the interview into the routine 
of taking a history and examining and treating the patient. The doctor then recorded the findings on a proforma after verbal consent was obtained from the patient. Details of the patient's age, gender, recent alcohol intake (within the previous six hours), amount of alcohol consumed in units, and history of previous assault were recorded. In addition, the location of the assault and details of the assailant were also taken (in this study domestic assault was defined as "assault by partner, ex-partner, or relative"). Details of the weapon used and resulting injuries were recorded. From the individual's postcode sector it was possible to give each person in the study a deprivation score according to the system devised by Carstairs and Morris. ${ }^{8}$ This deprivation score was used as an indicator of socioeconomic status. Statistical analysis was performed using $t$ test and $\chi^{2}$ test.

\section{Results}

DEMOGRAPHY

Two hundred and thirty five assault victims attended the $A \& E$ department during the study; $189(80 \%)$ were male and $46(20 \%)$ were female (mean age of females 29 years, range 11 to 58 years; mean age of males 28 , range 8 to 64$)$. Women were more likely than men to be attacked in their homes $(48 \% v$ $10 \%, P<0.001)$ and less likely to be attacked on the street $(26 \% v 44 \%, \mathrm{P}=0.023)$. Men were more likely to have recently consumed alcohol $(72 \%$ of men $v 52 \%$ of women, $\mathrm{P}=$ 0.0046), and those men who had been drinking consumed more than women drinkers (10.3 units $v 6.8$ units, $P=0.0033)$. In home based assaults, the woman was a victim of domestic assault on $82 \%$ of occasions, while the equivalent figure for men was $16 \%(P<0.001)$. Outside the home $50 \%$ of female assault victims were attacked by other women.

\section{WEAPONS AND INJURIES}

Knives (and weapons in general) were used less often in attacks on women-only $7 \%$ of attacks on women involved a penetrating sharp instrument compared with $28 \%$ of attacks on men $(P=0.003)$. Women were more likely to sustain a soft tissue injury; which was the main injury to $65 \%$ ("bruise/haematoma/abrasion/ contusion"), while this was the main injury to $34 \%$ of men $(P=0.04)$. Because of the greater number of attacks on men involving knives and glass, they were more likely to sustain injuries described as "laceration/stab/incision" than women-34\% $v 22 \%(P=0.01)$. ("Laceration" usually results from an attack with a blunt instrument, but on 20 occasions when the weapon used was a knife, the casualty doctor recorded the injury as "laceration".) Two of the three victims who were bitten were women and the two victims of attempted strangulation were also women. Women were more likely to be attacked about the face $(50 \% v 30 \%, P=$ 0.02).

Only $11 \%$ of women were admitted to hospital, compared with $31 \%$ of men ( $P=$ $0.005)$, which is in keeping with the relatively
Table 1 Comparison of female victims of domestic violence and victims of assault other than that carried out by a partner or relative (percentages in parentheses)

\begin{tabular}{|c|c|c|}
\hline & Domestic $(n=19)$ & Others $(n=27)$ \\
\hline \multicolumn{3}{|l|}{ Alcohol: } \\
\hline Yes & $14(74)$ & 9 (33) \\
\hline No & $5(26)$ & $18(67)$ \\
\hline P value ${ }^{\star}$ & \multicolumn{2}{|l|}{0.007} \\
\hline \multicolumn{3}{|l|}{ Unemployed: } \\
\hline Yes & $11(58)$ & $10(37)$ \\
\hline No & $8(42)$ & $17(63)$ \\
\hline P value ${ }^{\star}$ & \multicolumn{2}{|l|}{0.16} \\
\hline \multicolumn{3}{|c|}{ Deprivation score: } \\
\hline Mean & 3.12 & 2.02 \\
\hline$t$ & \multirow{2}{*}{\multicolumn{2}{|c|}{$\begin{array}{l}0.9983 \\
0.32\end{array}$}} \\
\hline$P$ valuet & & \\
\hline \multicolumn{3}{|c|}{ Previous assault: } \\
\hline Yes & $12(63)$ & $6(21)$ \\
\hline No & $5(26)$ & $21(78)$ \\
\hline Unknown & $2(11)$ & 0 \\
\hline P value ${ }^{\star}$ & \multicolumn{2}{|l|}{0.002} \\
\hline
\end{tabular}

${ }^{\star} \chi^{2}$ test.

$\dagger t$ test.

higher frequency of use of weapons against men. Equal proportions of men and women sustained fractures $(10 \%)$. One man died.

\section{DOMESTIC ASSAULT}

Domestic assault accounted for $9 \%$ of attacks and home based assault $17 \%$ in the overall study. In total, 19 of the 46 women ( $41 \%$ ) were victims of domestic assault and the assailant was usually married to the victim (husband 11, boyfriend 7 , father 1 ). A man was a victim of domestic assault on only two occasions ( $1 \%$ of the total number of attacks on men), significantly less than women $(P<0.001)$. All but one of the domestic assaults on women occurred in the home. Four of the female domestic assault victims were admitted to hospital. The others returned to their homesusually the very place where the assault occurred. The casualty doctors made no record in the case notes of those patients returning home regarding referral to the police, social services, or place of safety.

\section{COMPARISON OF FEMALE ASSAULT VICTIMS}

Compared with women not attacked by a partner or relative, women who were victims of domestic violence were older (mean age 33.9 years $v 27.1$ years) and more likely to have been drinking $(74 \% v 33 \%, P=0.007)$ and consuming more alcohol (mean of 9.6 units $v$ 4.2 units for those who had taken alcohol). Domestic assault victims often had a history of previous assault $(63 \% v 22 \%, P=0.002)$ (table 1).

Although more female victims of domestic assault were unemployed $(58 \% v 37 \%, \mathrm{P}=$ $0.16)$ and the group had a mean social deprivation score higher than the others (3.12 $v 2.02, \mathrm{P}=0.32$ ), the difference was not statistically significant.

\section{Discussion}

THE NATURE OF ASSAULT ON WOMEN

The findings in this study have highlighted the different nature of assault on women. They were much more likely than men to be assaulted in their own homes and by a partner or relative, although weapons were used less 
often than on men, and women were less likely to need admission to a hospital bed than men because of the lower proportion of serious injuries sustained.

The statistics on weapon use are similar to those in a report by Shepherd et al in Bristol, which highlighted the difference in wound patterns in males and females. In their study, proportionately more men sustained lacerations, consistent with the increased number of assaults with beer glasses or knives in men. ${ }^{9}$ Gayford also reported the frequent use of fists and feet in wife battering, with knives being used infrequently. ${ }^{7}$ Shepherd et al reported a much higher number of fractures to both males and females $(56 \%$ of women and $26 \%$ of men), ${ }^{10}$ while in Paisley only $10 \%$ of men and women had fractures. For men, an explanation can be found in the fact that fists and feet tend to cause fractures, and in the Bristol survey $72 \%$ of victims reported the use of fists or feet, while in Paisley fists or feet were used in only $43 \%$ of attacks, with knives and glass being used more commonly. ${ }^{4}$ However on $70 \%$ of occasions in Paisley, women were attacked with only fists and feet, and the commonest injury was soft tissue damage only, suggesting the possibility that less force was being used.

A higher percentage of the victims of domestic assault in this study was unemployed, but the difference was not statistically significant. However, research elsewhere has identified unemployment and poverty as predictors of domestic assault, ${ }^{11}$ something that $\mathrm{A} \& \mathrm{E}$ staff should be aware of (although there is no doubt that domestic violence can occur in all groups of patients, regardless of gender or socioeconomic status).

RECOGNISING VICTIMS OF DOMESTIC ASSAULT Since 1981, the largest increase in violence reported by the British Crime Survey has been in domestic incidents: 3.4 times more in $1995 .{ }^{12}$ Although some of this increase may be due to a greater willingness on the part of the victim to report the crime, nevertheless there is a pressing need to address the problem of domestic violence. This study has revealed some differences between the group of women who were the victims of domestic violence and the group who were not. If a doctor interviews any woman who has been assaulted in her home, has been drinking, or admits to previous assault, they should be alerted to the possibility of domestic assault. This may seem obvious, but research suggests that doctors fail to recognise a significant proportion of domestic assault victims. The majority of such victims in this study appear to have been treated and then sent home without receiving any advice or counselling, suggesting that even when such an assault is recognised, not enough is being done for the victim. The fact that $70 \%$ of Scottish female homicide victims are killed in domestic disputes, while domestic assaults are known to be recurrent, suggests that this is one area where a more active role by $\mathrm{A} \& \mathrm{E}$ staff could have an impact in controlling the number of such attacks. Ward et al have commented on the fact that children of women who are victims of domestic assault are at increased risk themselves, and $A \& E$ staff should be aware of this increased risk. ${ }^{13}$

DEALING WITH DOMESTIC ASSAULT IN THE ACCIDENT AND EMERGENCY DEPARTMENT Victim Support is the national charity which helps victims of crime. It has published guidelines and reports on domestic violence, including guidelines for health professionals ${ }^{14}$ and recommends the guidelines for the recognition and management of domestic violence in the A\&E department provided by the British Association for Accident and Emergency Medicine. ${ }^{15}$ The guidelines emphasise that staff in the $A \& E$ department need to be especially vigilant when a female victim of assault comes for treatment, in order to identify those victims of domestic assault. Ideally, there should be 24 hour access to a social worker (in theory this already exists but the service is underused) and access to a place of safety. The victim should be put in contact with a dedicated agency and offered the option of contacting the police. Computerised record keeping in A\&E departments, incorporating programmes dedicated to injuries, could, if organised in a systematic way, enable the staff to recognise recurrent domestic assault, possibly incorporating the child abuse register. The general practitioner should always be informed; the victim may well be attending with physical or emotional symptoms and the opportunity for counselling should not be lost. It must always be borne in mind that most victims of domestic assault do not say that they have been assaulted, ${ }^{56}$ and may present with such things as "accidental injury," overdose, self harm, alcohol/drug abuse, depression, and so on. This study no doubt underestimated the incidence of domestic assault in Paisley, as we only looked at self admitted assault. It would be interesting to see if this is just the tip of the iceberg by conducting a study which attempted to incorporate all the various forms of presentation of domestic assault.

There is a role for the education and training of $A \& E$ staff in recognising and dealing with victims of domestic assault.

We would like to thank all the A\&E staff for helping with the data collection, and especially the consultant, Mr Charles Allister, for allowing for the study to take place. Thanks to Dr Neeraj Prasad for advice on writing the paper.

1 Homicide in Scotland 1985-1994. The Scottish Office. Statistical Bulletin, Criminal Justice Series. London: HMSO, 1995.

2 Hocking MA. Assaults in south east London. J R Soc Med 1989;82:281-4.

3 Fligelstone LJ, Johnson RC, Wheeler MH, Salaman JR. An audit of stab wounds in Cardiff. J R Coll Surg Edinb 1995; 40:167-70.

4 Shepherd J. Violent crime in Bristol: an accident and emergency department perspective. Br J Criminol 1990;30:289305.

5 Hamberger LK, Saunders DG, Hovey M. Prevalence of domestic violence in community practice and rate of physician inquiry. Fam Med 1992;24:283-7.

6 Randall T. Domestic violence calls for more than treating injuries. JAMA 1990;264:939-40.

7 Gayford JJ. Wife battering: a preliminary survey of 100 cases. BMJ 1975;i:194-7.

8 Carstairs V, Morris R. Deprivation and health in Scotland. Aberdeen: Aberdeen University Press, 1991.

9 Shepherd JP, Shapland M, Pearce NX, Scully C. Pattern, severity and aetiology of injuries in victims of assault. J R Soc Med 1990;83:75-8. 
10 Shepherd JP, Gayford J, Leslie IJ, Scully C. Female victims of assault: a study of hospital attenders. J Craniomaxillofac Surg 1988;16:233-7.

11 Gelles RJ. Violence in the family: a review of research in the seventies. J Marriage Fam 1980;42:873-85.

12 Mirrlees-Black C, Mayhew P, Percy A. The 1996 British crime survey. London: Home Office Statistical Bulletin,
1996 .
13 Ward L, Shepherd JP, Emond AM. Relationship between adult victims of assault and children at risk of abuse. BMJ 1993;306:1101-2.

14 Victim Support. Supporting victims of domestic violence: guidelines. London: Victim Support, 1991.

15 British Association for Accident and Emergency Medicine. Domestic violence: recognition and management in $A \mathcal{E} E$. London: Royal College of Surgeons, 1993.

\section{Pre-Hospital Immediate Care}

"Towards Evidence-Based Pre-Hospital Care"

\section{One day conference}

\section{Thursday 5th March 1998 \\ Commonwealth Institute \\ High Street Kensington, London W8}

Following the success of the first Pre-hospital Immediate Care conference held in March 1997, this second conference will focus on evidence-based pre-hospital care-a method ensuring that clinical decision making is based on the best available evidence.

The conference is aimed at:

- Pre-hospital care and the emergency services

- Emergency doctors and nurses

- Paramedics

- EMTs

- Anyone with a strong interest in pre-hospital care.

\section{Scientific programme}

The scientific programme will be made up of plenary sessions combined with a series of practical workshops. Keynote speakers will address areas of growing importance.

\section{Posters and free papers-call for abstracts}

For authors' instructions and further information please contact Kathryn Sims, BMJ Publishing Group, BMA House, Tavistock Square, London, WC1H 9JP, Tel 0171383 6795, Fax 0171383 6668, Email 101317.477@compuserve.com

\section{Exhibition}

A commercial exhibition will take place during the conference. Companies or organisations wishing for further information should contact Jane Lewis at the address below.

\section{Registration}

For a registration form and further information please contact Jane Lewis, BMA Conference Unit, BMA House, Tavistock Square, London, WC1H 9JP. Tel 0171383 6605, Fax 0171383 6663, Email JaneLewis@BMA.org.com 